\title{
Assessment of Semi-Quantitative Health Risks of Exposure to Harmful Chemical Agents in the Context of Carcinogenesis in the Latex Glove Manufacturing Industry
}

\author{
Saeed Yari ${ }^{1 *}$, Ayda Fallah Asadi², Sakineh Varmazyar ${ }^{3}$
}

\begin{abstract}
Excessive exposure to chemicals in the workplace can cause poisoning and various diseases. Thus, for the protection of labor, it is necessary to examine the exposure of people to chemicals and risks from these materials. The purpose of this study is to evaluate semi-quantitative health risks of exposure to harmful chemical agents in the context of carcinogenesis in a latex glove manufacturing industry. In this cross-sectional study, semi-quantitative risk assessment methods provided by the Department of Occupational Health of Singapore were used and index of LD50, carcinogenesis (ACGIH and IARC) and corrosion capacity were applied to calculate the hazard rate and the biggest index was placed as the basis of risk. To calculate the exposure rate, two exposure index methods and the actual level of exposure were employed. After identifying risks, group $\mathrm{H}$ (high) and $\mathrm{E}$ (very high) classified as high-risk were considered. Of the total of 271 only $39(15 \%)$ were at a high risk level and 3\% were very high (E). These risks only was relevant to 7 materials with only sulfuric acid placed in group E and 6 other materials in group $\mathrm{H}$, including nitric acid (48.3\%), chromic acid (6.9\%), hydrochloric acid (10.3\%), ammonia (3.4\%), potassium hydroxide $(20.7 \%)$ and chlorine (10.3\%). Overall, the average hazard rate level was estimated to be 4 and average exposure rate to be 3.5. Health risks identified in this study showed that the manufacturing industry for latex gloves has a high level of risk because of carcinogens, acids and strong alkalisand dangerous drugs. Also according to the average level of risk impact, it is better that the safety design strategy for latex gloves production industry be placed on the agenda.
\end{abstract}

Keywords: Risk assessment - chemical agents - latex glove production - protection

Asian Pac J Cancer Prev, 17, Cancer Control in Western Asia Special Issue, 205-211

\section{Introduction}

Chemicals are widely used to produce a range of consumer needs (Egeghy, Vallero et al. 2011). By increasing the production and use of chemicals, the risk of exposure to material was increase (Callahan and Sexton 2007). So people during their working life, especially in environments exposed to various chemical substances (Schenk, Hansson et al., 2008). Workplace chemical contaminants, including gases, vapors and solid and liquid particles, each of these has specific risks and losses that result from them depending on the type of chemical, route of entry, location, duration and density have been different and cause disease in exposed workers . In addition to the workers, their families are often exposed to these infections because the chemicals in several ways, such as clothes, hair, shoes and home workers are entry and followed by it, will have irreparable damage to the wife and children of workers (Laforest, Annino et al. ,1999). Chemical substances enter the human body through different routes, generally, in toxicology tests, oral route is the first route (Geraets, Bessems et al., 2014). On the other hand, different chemicals have different toxicities. Excessive exposure to chemicals in the workplace can cause poisoning and various diseases. These risks are particularly related to the production and use of chemicals in different processes (Money and Margary 2002). The health effects caused by exposure to these chemicals can be classified into three groups: acute or chronic effects, systemic or local effects and reversible and irreversible effects (Herber, Duffus et al., 2001). In order to achieve health objectives for the protection of labor, it is necessary that exposure to chemicals and risks of these substances to be examined (Fromme, Albrecht et al., 2007). Because the health risk assessment of chemicals to determine their effects. Health risk assessment of exposure to chemical and toxic materials is to determine the level of risk, will also enable us to make the right decisions for the measures needed to protect people (Manpower 2005). Nowadays, a wide range of models for health risk assessment was used (Fryer, Collins et al., 2006). Each of the proposed methods has shortcomings; but the ultimate goal of all of them

${ }^{1}$ Students Research Committee, Department and Faculty of Health, Shahid Beheshti University of Medical Sciences, Tehran, ${ }^{2}$ Health Network in Bouin Zahra, ${ }^{3}$ Faculty of Occupational Health Engineering in Health Department, Qazvin University of Medical Sciences, Qazvin, Iran, *For correspondence: smaeedy@gmail.com 
provide conditions when making decisions, particularly in relation to the control and optimization of working conditions can prioritize risks and directed a development costs that are often limited, in most important risks in the field of control (Swaen and Meijers 1989). At the moment, information of estimates of health risks and the human environment for the more than 10,000 existing chemical composition, is incomplete. And every year, hundreds of other combinations are added to this amount, also potential of most commercially produced materials are used for quantification of exposure to humans (Egeghy, Vallero et al. 2011). Also there are many chemicals which were formerly known as safety or low risk materials for humans and later, with the risk assessment and the relevant tests as carcinogens (eg asbestos) or support genital disorders (eg thalidomide) were introduced. Risk assessment can be one of the most important strategies in the field of identification and control of chemical exposures, the purpose of the risk assessment of chemicals, detection and quantification of risks associated with the use of a harmful chemical substance (Drexler and Shukla, 2014). In definition Aven, knows risk as a two-dimensional concept that including accidents and their consequences and unknown possibilities associated with them, in this definition, the risk, is the probability rate of an accident and its consequences, which consider to determine the various parameters of the probability and severity of accidents (Aven 2009, Yari 2015). Toxicological risk assessment allows evaluating the public health conditions (Normohammadi, Kakooei et al. 2016). And also the purpose of the risk assessment identify the potential risks of chemicals, including chemicals, assessment of workers' exposure with harmful chemicals and determine the risk of unintended harmful effects on people, is caused by exposure to harmful chemical substances (Manpower 2002, de Joode, Vermeulen et al., 2005, Manpower 2005). Risk assessment is a process that combines the risk, exposure and dose-response data to determine risk population exposed workers to provide health information needed for risk management (Askham, Gade et al., 2013). In the early stages of chemical plant design, chemical process route is one of the main design decisions. Previously, was the most important factor in choosing the best path to economic chemical process but now, according to the results of the risk assessment, safety, environment and occupational health issues to be selected (Hassim and Edwards 2006). Risk, safety instructions and strategy is necessary to risk management and safety to be implemented widely and comprehensive inter-agency (Mearns and Yule 2009). According to mentioned content, the purpose of this study was to evaluate semi-quantitative health risks of exposure to harmful chemical agents with the approach of carcinogenesis in a latex glove manufacturing industry.

\section{Materials and Methods}

This cross-sectional study was conducted in one of the glove manufacturing industry with latex base and the method used to assess the health risk of exposure to harmful chemical agents, using semi-quantitative risk assessment provided by the Department of Occupational Health of Singapore (Manpower 2005) that the procedure is as follows:

1. First, a working group was formed consisting of representatives of the employer, workers' representatives, health professionals, safety expert and the head of each unit, and information on how to do the work, materials used and the different ways of dealing with them in cooperation with the committee members was provided.

2. Provide a listing of the units and vacancies in each unit and finally break each job into smaller tasks so that employees with similar jobs were placed in a group.

3. Identify all the chemicals, such as raw materials, Interstitial, main products and secondary products that use or produce, including solid, liquid, gas, vapor, dust, mist or fumes regardless of the type of controls.

4. Determination of the hazard rate of each chemical detected based on the amount or toxicity risks of these substances to one of the following methods:

A) Obtaining the hazard rate with the use of toxic or harmful effects of chemicals (Table 1).

B) Determining the hazard rate to the acute toxicity of chemicals by determining the lethal dose (LD50) and lethal concentration (LC50) extracted from the MSDS chemicals (Table 2).

5. Interview with workers about process and work with them in order to understand whether employees exposed to toxic substances or not.

6. Considering of the amount, frequency, route and duration of exposure for workers who have been exposed to chemicals or may be exposed to it and using these factors to calculate the exposure rate, when the exposure monitoring results are not available.

7. Determining the exposure rate (ER) with each of the chemicals in the following ways:

A) Determining of the exposure rate using the actual level of exposure: When the results of measuring the concentration of chemical substances (air monitoring) are available, the mean weekly exposure to chemical agents using the following equation can be obtained.

In the above equation is assumed that when at rest (when a job duty is not done) the person is not dealing with chemicals. After calculating the weekly average exposure (E) by Table 3 the exposure rate is determined.

$$
E=\frac{F \times D \times M}{W}
$$

W: average hours worked per week (40 hours)

D: The average time of exposure

$\mathrm{F}$ : number of exposures in the week

$\mathrm{M}$ : exposure (ppm or $\mathrm{mg} / \mathrm{m} 3$ )

E: The weekly exposure (ppm or mg / $\mathrm{m} \mathrm{3}$ )

B) Determining the exposure rate using the exposure index: In the event that the results of air monitoring (measurement of exposure value) is not available, the exposure rate can be achieved through the following equation:

Exposure index is obtained in terms of a rating 5 each (from one to five) and according to Table 4 where in 1: negligible, 2: low, 3: medium, 4: high, and 5: very high. In this study, four factors, exposure to steam pressure, control 
Table 1. Determination of Hazard Rate (HR) with Using to Toxic Effect or Detrimental Chemicals Complication (Manpower 2005)

\begin{tabular}{|c|c|c|}
\hline HR & $\begin{array}{l}\text { Describe the effects of chemicals on the classification of chemical } \\
\text { hazardous }\end{array}$ & Example \\
\hline 1.0 & $\begin{array}{l}\text { - Substances which no health effects are not known and are not } \\
\text { classified as toxic or harmful. } \\
\text { - Substances that the ACGIH put them in the A5 Carcinogens } \\
\text { class. }\end{array}$ & $\begin{array}{l}\text { Sodium chloride, butane, butyl acetate, calcium } \\
\text { carbonate }\end{array}$ \\
\hline 2.0 & $\begin{array}{l}\text { - Substances that are reversible effects on the skin, eyes and } \\
\text { mucous membranes, but their effect is not so severe that humans can } \\
\text { cause serious problems. } \\
\text { - Substances that the ACGIH put them in the A4 Carcinogens } \\
\text { class. } \\
\text { - } \quad \text { Substances that cause allergies and irritation to the skin. }\end{array}$ & $\begin{array}{c}\text { Acetone, butane, acetic acid (10\%), salts of } \\
\text { barium and ... }\end{array}$ \\
\hline 3.0 & $\begin{array}{l}\text { - Substances that likely Carcinogenic or mutagenic to humans or } \\
\text { animals, but there is no enough information in this regard. } \\
\text { - Substances that the ACGIH put them in the A3 Carcinogens } \\
\text { class. } \\
\text { - } \quad \text { Substances that the IARC put them in the } 2 \text { B Group. } \\
\text { - } \quad \text { Corrosive substances }(3.0<\mathrm{PH}<5.0 \text { or } 9.0<\mathrm{PH}<12.0) \text { and } \\
\text { respiratory sensitizer and }\end{array}$ & $\begin{array}{l}\text { Toluene, xylene, ammonia, butanol, acetalde- } \\
\text { hyde, aniline, antimony }\end{array}$ \\
\hline 4.0 & $\begin{array}{l}\text { - Substances that might be carcinogenic, mutagenic (causing } \\
\text { gene mutation) and teratogenic (malformations), which according to } \\
\text { studies carried out on animals more than the previous category. } \\
\text { - } \quad \text { Substances that the ACGIH put them in the A2 Carcinogens } \\
\text { class. } \\
\text { - } \quad \text { A2Group in IARC classification } \\
\text { - } \quad \text { Very corrosive materials }(0<\mathrm{PH}<2.0 \text { or } 11.0 / 5.0<\mathrm{PH}<14.0)\end{array}$ & $\begin{array}{l}\text { Formaldehyde, cadmium, methylene chloride, } \\
\text { ethylene oxide, acrylonitrile }\end{array}$ \\
\hline 5.0 & $\begin{array}{l}\text { - Substances with carcinogenic effects, mutagenic (causing gene } \\
\text { mutation) and teratogenic (malformations) are known. } \\
\text { - Substances that the ACGIH put them in the A1 Carcinogens } \\
\text { class. } \\
\text { - } \quad \text { Group } 1 \text { in IARC classification } \\
\text { - } \quad \text { Very toxic chemicals }\end{array}$ & $\begin{array}{l}\text { Benzene, benzidine, lead, arsenic, beryllium, } \\
\text { bromine, polyvinyl chloride, mercury }\end{array}$ \\
\hline
\end{tabular}

measures, the amount used in the week and working time per week were used.

Formula (2)

$$
E R=\left[E I_{1} \times E I_{2} \times E I_{3} \times \ldots \times E I_{n}\right]^{\frac{1}{n}}
$$

$\mathrm{n}$ : The number of exposure factors used

8. Calculating the risk factor according to the following equation:

Formula (3)

$$
\sqrt{(H R \times E R)}
$$

HR: Hazard rate (scale of 1 to 5 in Table 1 and 2)

ER: Exposure rate (scale of 1 to 5 in Table 3 )

9. Risk ratings based on risk ranking matrix in Figure 1 (Manpower 2005). To rank the risks of negligible $(\mathrm{P})$, low $(\mathrm{L})$, medium $(\mathrm{M})$, high $(\mathrm{H})$ and very high $(\mathrm{E})$ scales were used.

In this study, LD50 and carcinogenic (ACGIH and IARC) index and the risk of corrosion was used to calculate the hazard rate and the biggest index was used as the basis of hazard rate. For calculating the exposure rate, two methods of exposure index and the actual level of exposure were used. And after determining risk by equation (3) of available risks were prioritized by risk ranking matrix (Figure 1). In the present study, the risks that were in group $\mathrm{H}$ and $\mathrm{E}$ were considered as high risk, in other words, cut of point was identified risks of group $\mathrm{M}$, finally, recommendations were provided to control and reduce risks to an acceptable level.

\begin{tabular}{|c|c|c|c|c|}
\hline HR & $\begin{array}{l}\text { LD50 absorbed by } \\
\text { mouth ( } \mathrm{mg} / \mathrm{kg} \text { body } \\
\text { weight of rat) }\end{array}$ & $\begin{array}{l}\text { LD50 dermal absorption } \\
\text { (mg / } \mathrm{kg} \text { body weight of rat) }\end{array}$ & $\begin{array}{c}\text { LC50 absorbed } \\
\text { by inhalation in rat (mg / } \\
\text { lit gases and vapors in } 4 \\
\text { hours) }\end{array}$ & $\begin{array}{l}\text { LC50 absorbed by inhalation } \\
\text { in rat ( } \mathrm{mg} / \text { lit aerosols and } \\
\text { particulate matter in } 4 \text { hours) }\end{array}$ \\
\hline 2.0 & $2,000.0>$ & $2,000.0>$ & $20.0>$ & $5.0>$ \\
\hline 3.0 & $2,000.0>200<\mathrm{LD} 50$ & $2,000.0>400<$ LD50.0 & $20.0>2.0<\mathrm{LC} 50.0$ & $5.0>1.0<\mathrm{LC} 50.0$ \\
\hline 4.0 & $200.0><$ LD50.0 25.0 & $400.0><$ LD50.0 50.0 & $2.0>0.5<\mathrm{LC} 50.0$ & $1.0>0.25<\mathrm{LC} 50.0$ \\
\hline 5.0 & $25.0>$ LD50.0 & $50.0>$ LD50.0 & $0.5>\operatorname{LC} 50.0$ & $0.25>\mathrm{LC} 50.0$ \\
\hline
\end{tabular}

Table 2. Determination of Hazard Rate (HR) Through Acute Toxicity of Chemicals (Manpower 2005) 
Table 3. Determination of Exposure Rate(ER) (Manpower 2005)

\begin{tabular}{ll}
\hline ER & E/PEL \\
\hline 1.0 & Under 0.1 \\
2.0 & $0.1-0.5$ \\
3.0 & $0.5-1.0$ \\
4.0 & $1.0-2.0$ \\
5.0 & More 2.0 \\
\hline
\end{tabular}

\section{Results}

Desired industry which produces household and industrial gloves with latex base, generally has 10 units and 196 employees, respectively the manufacturing process consists of a producing material $(n=12)$, three production units (lines $1(\mathrm{n}=18)$, line $2(\mathrm{n}=18)$ and Line 5 (18 person), a gloves washing unit (14 person), a first dryer unit (3 person), a second dryer unit (3 person), a packaging unit (73), quality control $(n=25)$ and maintenance (12 person). Because of the chemicals in material production units, production and washing gloves, only these three units were studied, so the staff of maintenance and quality control which was attended by a cross-sectional in this hall were also placed in study groups. Activities identified in material production unit was including jobs of material production $(\mathrm{n}=$ $12)$, repairs ( 3 person) and quality control ( 2 person) that on average 7 hours for material producer staff, one hour for maintenance staff and 3 hours per day for quality control staff were presented at the hall and duties of material producer staff were including the combination of materials to help pumps and valves in various tanks and mixers, monitoring operation and fill out relevant forms and the check list. Duties of maintenance staff was to repair and equip pipes, pumps and valves, tanks, welding, inspection of tanks and valves, repair power and etc. And the duties of quality control staff to undertake that were included in the sampling of materials, inspection of thermometers, barometers, pressure gauges and other instruments recorded in the corresponding check list. In Table 5, exposure rate, risk degree and risk rating of these jobs were shown in material production unit.

There are also jobs in production units such as stripper (15 person per production line), audit ( 3 person per production line), quality control (3 person per production line) and repair ( 2 person) an average, 7 hours for stripper and inspection staff, 4 hours for quality control staff and 2 hours per day for maintenance staff were presented at production halls (production lines 1,2 and 5). Stripper staff undertook the task of pulling the gloves of templates, inspector staff is doing tasks such as inspection of pipelines, supervising the work of stripper, monitoring devices and instrumentation of lines and fill out relevant forms and the check list. Quality control staff undertook the task of sampling material, sampling and testing gloves, inspection of the thermometer, barometers, density gauges and other instrument and record information on the relevant check list and maintenance staff undertook the task of repair and equip pipes, pumps, valves, tanks and dipper and welding, repair power and etc. that the results of their risk assessment (production line 1) is shown in Table 6. The results of their risk assessment of production line 2 and 5 is as the results of the risk assessment of line

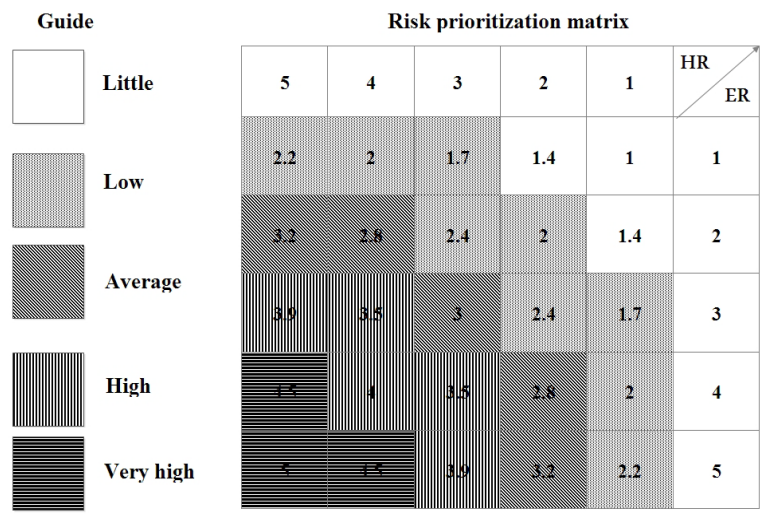

Figure 1. Risk Prioritization Matrix

Table 4. Determination of Exposure Index (EI) (Manpower 2005)

\begin{tabular}{|c|c|c|c|c|c|}
\hline $\begin{array}{l}\text { EI } \\
\text { Exposure factor }\end{array}$ & 1 & 2 & 3 & 4 & 5 \\
\hline vapor pressure & Less than $0.1 \mathrm{mmHg}$ & 0.1 to $1.0 \mathrm{mmHg}$ & 1.0 to $10.0 \mathrm{mmHg}$ & $\begin{array}{l}10.0 \text { to } 100.0 \\
\mathrm{mmHg}\end{array}$ & $\begin{array}{c}\text { More than } 100.0 \\
\text { mmHg }\end{array}$ \\
\hline $\begin{array}{l}\text { Particle size in } \\
\text { terms aerody- } \\
\text { namic diameter }\end{array}$ & $\begin{array}{l}\text { Coarse particles or } \\
\text { wet material }\end{array}$ & $\begin{array}{l}\text { Coarse and dry } \\
\text { materials }\end{array}$ & $\begin{array}{l}\text { dry and more than } \\
100.0 \mu \mathrm{m}\end{array}$ & $\begin{array}{l}\text { Small and dry } \\
10.0 \text { to } 100.0 \mu \mathrm{m} \\
\text { materials }\end{array}$ & $\begin{array}{l}\text { Powder, dry, small } \\
\text { and less than } 10.0 \\
\mu \mathrm{m}\end{array}$ \\
\hline Ratio OT / PEL & Less than 0.1 & 0.1 to 0.5 & 0.5 to 1.0 & 1.0 to 2.0 & More than 2.0 \\
\hline $\begin{array}{l}\text { Control meas- } \\
\text { ures }\end{array}$ & $\begin{array}{l}\text { Adequately } \\
\text { controlled with } \\
\text { regular maintenance }\end{array}$ & $\begin{array}{l}\text { Adequate control } \\
\text { with irregular } \\
\text { maintenance }\end{array}$ & $\begin{array}{c}\text { adequate control With- } \\
\text { out maintenance (the } \\
\text { dust average) }\end{array}$ & $\begin{array}{l}\text { Inadequate con- } \\
\text { trol (high dust) }\end{array}$ & $\begin{array}{l}\text { Without control } \\
\text { (very high dust) }\end{array}$ \\
\hline $\begin{array}{l}\text { The amount used } \\
\text { in the week }\end{array}$ & $\begin{array}{c}\text { The amount use is } \\
\text { negligible Less than } \\
1.0 \mathrm{~kg} \text { or liter }\end{array}$ & $\begin{array}{c}\text { The amount used } \\
\text { is small } \\
1.0 \text { to } 10.0 \mathrm{~kg} \text { or } \\
\text { liter }\end{array}$ & $\begin{array}{l}\text { The amount used is } \\
\text { average, } \\
\text { Workers have been } \\
\text { trained in the transport } \\
\text { of chemicals. } \\
10.0 \text { to } 100.0 \mathrm{~kg} \text { or } \\
\text { liter }\end{array}$ & $\begin{array}{l}\text { The amount used } \\
\text { is high, } \\
\text { workers are } \\
\text { trained to work } \\
\text { with chemicals } \\
100 \text { to } 1000 \mathrm{~kg} \\
\text { or liter }\end{array}$ & $\begin{array}{l}\text { The amount used } \\
\text { is high, } \\
\text { The workers not } \\
\text { trained to work } \\
\text { with chemicals } \\
\text { More than } 1000 \mathrm{~kg} \\
\text { or liters }\end{array}$ \\
\hline $\begin{array}{l}\text { Hours worked } \\
\text { per week }\end{array}$ & Less than 8.0 hours & 8.0-16.0 .0hours & $16.0-24.0$ hours & 24.0-32.0 hours & $32.0-40.0$ hours \\
\hline
\end{tabular}


Table 5. Health Risk Assessment of Exposure to Chemical Contaminants Identified in the Material Production unit

\begin{tabular}{|c|c|c|c|c|c|c|c|c|c|c|c|c|}
\hline \multirow[b]{3}{*}{ Material Name } & \multirow[b]{3}{*}{$\begin{array}{l}\mathbb{T} \\
\stackrel{N}{N} \\
\stackrel{0}{0} \\
\overrightarrow{0} \\
\overrightarrow{0} \\
\overrightarrow{0}\end{array}$} & \multicolumn{11}{|c|}{ Unit } \\
\hline & & \multicolumn{3}{|c|}{ Material Building } & \multirow[b]{2}{*}{$\begin{array}{l}\mathbb{T} \\
\text { N } \\
\stackrel{0}{0} \\
\overrightarrow{0} \\
\overrightarrow{0} \\
\overrightarrow{0}\end{array}$} & \multicolumn{2}{|c|}{ Maintenance } & \multirow[b]{2}{*}{ 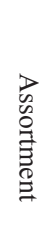 } & \multirow[b]{2}{*}{$\begin{array}{l}\mathbb{T} \\
\stackrel{N}{N} \\
\stackrel{0}{0} \\
\overrightarrow{0} \\
\overrightarrow{0} \\
\overrightarrow{0}\end{array}$} & \multicolumn{3}{|c|}{ Quality control } \\
\hline & & $\begin{array}{l}\mathbb{1} \\
\dot{x} \\
0 \\
0 \\
0 \\
0 \\
0 \\
0 \\
\overrightarrow{0}\end{array}$ & 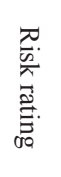 & 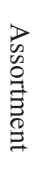 & & $\begin{array}{l}\text { T) } \\
\frac{x}{0} \\
0 \\
\vdots \\
0 \\
0 \\
0 \\
\overrightarrow{0}\end{array}$ & . & & & $\begin{array}{l}\mathbb{1} \\
\text { x. } \\
0 \\
0 \\
0 \\
0 \\
0 \\
0 \\
\overrightarrow{0} \\
\overrightarrow{0}\end{array}$ & 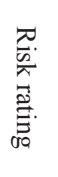 & $\begin{array}{l}\vec{P} \\
0 \\
0 \\
O \\
\Xi \\
0 \\
己 \\
己\end{array}$ \\
\hline Oleic acid & 2.0 & 3.0 & 2.4 & $\mathrm{~L}$ & 2.0 & 2.0 & 1.9 & $\mathrm{~L}$ & 2.0 & 2.0 & 2.2 & $\mathrm{~L}$ \\
\hline Acid casein & 1.0 & 2.0 & 1.5 & $\mathrm{~L}$ & 1.0 & 2.0 & 1.3 & $\mathrm{P}$ & 1.0 & 2.0 & 1.4 & $\mathrm{P}$ \\
\hline Sulfuric acid & 5.0 & 3.0 & 3.6 & $\mathrm{H}$ & 5.0 & 2.0 & 2.9 & M & 5.0 & 2.0 & 3.4 & M \\
\hline Nitric acid & 4.0 & 3.0 & 3.7 & $\mathrm{H}$ & 4.0 & 2.0 & 3 & M & 4.0 & 3.0 & 3.5 & $\mathrm{H}$ \\
\hline Acetic acid & 3.0 & 2.0 & 3.6 & M & 3.0 & 2.0 & 2.2 & $\mathrm{~L}$ & 3.0 & 2.0 & 2.5 & $\mathrm{~L}$ \\
\hline Latex & 2.0 & 3.0 & 2.4 & $\mathrm{~L}$ & 2.0 & 2.0 & 1.9 & $\mathrm{~L}$ & 2.0 & 2.0 & 2.2 & $\mathrm{~L}$ \\
\hline Zinc oxide & 2.0 & 2.0 & 2.2 & $\mathrm{~L}$ & 2.0 & 2.0 & 1.8 & $\mathrm{~L}$ & 2.0 & 2.0 & 2.0 & $\mathrm{~L}$ \\
\hline 2-Benzothiazolethione & 1.0 & 2.0 & 1.5 & $\mathrm{~L}$ & 1.0 & 2.0 & 1.3 & $\mathrm{P}$ & 1.0 & 2.0 & 1.4 & $\mathrm{P}$ \\
\hline diethylcarbamodithioato-S-S' & 2.0 & 2.0 & 2.2 & $\mathrm{~L}$ & 2.0 & 2.0 & 1.8 & $\mathrm{~L}$ & 2.0 & 2.0 & 2.0 & $\mathrm{~L}$ \\
\hline Ammonia & 3.0 & 4.0 & 3.4 & $\mathrm{H}$ & 3.0 & 3.0 & 2.8 & M & 3.0 & 3.0 & 3.2 & M \\
\hline Titanium dioxide & 3.0 & 2.0 & 2.6 & M & 3.0 & 2.0 & 2.2 & $\mathrm{~L}$ & 3.0 & 2.0 & 2.5 & M \\
\hline Calcium carbonate & 2.0 & 3.0 & 2.3 & $\mathrm{~L}$ & 2.0 & 2.0 & 1.9 & $\mathrm{~L}$ & 2.0 & 2.0 & 2.1 & $\mathrm{~L}$ \\
\hline Potassium hydroxide & 4.0 & 3.0 & 2.3 & $\mathrm{H}$ & 4.0 & 2.0 & 2.7 & $\mathrm{~L}$ & 4.0 & 2.0 & 3.1 & M \\
\hline Paraffin & 1.0 & 2.0 & 1.5 & $\mathrm{~L}$ & 1.0 & 2.0 & 1.3 & $\mathrm{P}$ & 1.0 & 2.0 & 1.4 & $\mathrm{P}$ \\
\hline Sulfur & 4.0 & 2.0 & 3.1 & M & 4.0 & 2.0 & 2.5 & M & 4.0 & 2.0 & 2.9 & M \\
\hline kumanox & 1.0 & 3.0 & 1.8 & $\mathrm{~L}$ & 1.0 & 2.0 & 1.4 & $\mathrm{P}$ & 1.0 & 3.0 & 1.6 & $\mathrm{~L}$ \\
\hline
\end{tabular}

1 with this difference that the risk rate of sulfuric acid and chromic acid in line 2 for the four types of jobs is equal to 2.2 and chromic acid for stripper and inspector of line 5 is equal to 3.2 .

In washing gloves unit, four types of jobs: driver (1 person), washing machine operator (9 person), quality control ( 3 person) and maintenance ( 2 person) was performed that driver undertook the task of carrying and weighing carts and record information on the relevant forms. Device operator undertook the task of carrying hydrochloric acid and sodium hypochlorite, launching devices and monitoring the device, quality control staff with the inspection of the environments and devices, sampling of hydrochloric acid and sodium hypochlorite, sampling gloves and record information in the relevant form and check list undertook their task, maintenance staff undertook the task of repair and equipment, valves, fittings, pumps, etc. On average 5 hours for driver, 7 hours

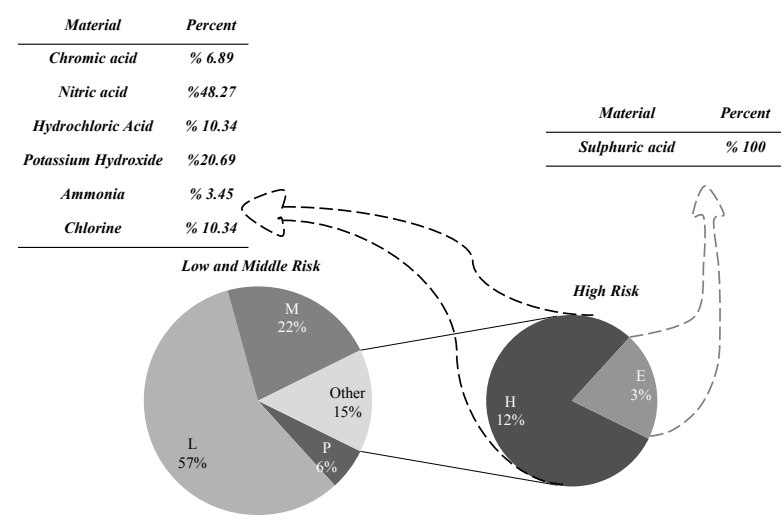

Figure 2 : Frequency of Identified Risks for operator staff, 5 hour for quality control staff and 1 hour per day for repair were presented at the hall. The results of the risk assessment of this unit staff are also shown in Table 7.

According to Diagram 2, the most identified risks were placed in low group (L) (57\%) and risks that were identified as high risk were a total of $15 \%$ of that $3 \%$ of them were very high (E). High level identified risks in material production units was related to sulfuric acid at material production job, nitric acid at material production job and quality control, ammonia and potassium hydroxide at material production job. These risks in production lines was related to sulfuric acid in jobs of stripper, inspection, quality control and maintenance of lines 1 and 5, nitric acid in every four jobs in all lines, chromic acid in jobs of stripper and inspection line 1 and potassium hydroxide in jobs of stripper and inspect all lines. In gloves washing unit, these risks was related to hydrochloric acid and chlorine in jobs of operator, driver and quality control. So from 271 known risk according to Diagram 2, only 39 risk $(15 \%)$ were at high level that these risks were only related to 7 substances contains sulfuric acid, nitric acid, chromic acid, hydrochloric acid, ammonia, potassium hydroxide and chlorine. The frequency of each of these substances is identified in Diagram 2, according to this diagram, the highest frequency in Group H was related to nitric acid (48.3\%) and in Group E was only in sulfuric acid. Overall, the average of hazard rate in high level was estimated 4 and the average of exposure rate was estimated 3.5.

\section{Discussion}

Health risks identified in this study showed that the 
Table 6. Health Risk Assessment of Exposure to Chemical Contaminants Identified in One Line Production

\begin{tabular}{|c|c|c|c|c|c|c|c|c|c|c|c|c|c|c|c|c|}
\hline \multirow[b]{3}{*}{ Material Name } & \multicolumn{16}{|c|}{ Unit } \\
\hline & \multicolumn{4}{|c|}{ Stripper } & \multicolumn{4}{|c|}{ Inspection } & \multicolumn{4}{|c|}{ Maintenance } & \multicolumn{4}{|c|}{ Quality control } \\
\hline & 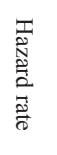 & 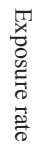 & 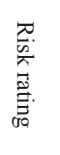 & 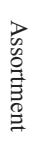 & 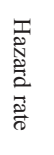 & 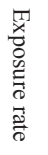 & 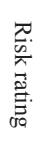 & 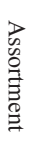 & 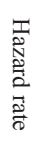 & 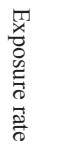 & 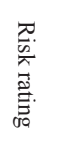 & 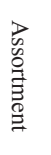 & 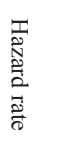 & 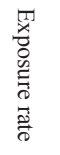 & 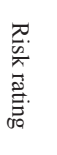 & 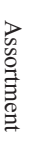 \\
\hline Oleic acid & 2.0 & 3.0 & 2.4 & $\mathrm{~L}$ & 2.0 & 3.0 & 2.4 & $\mathrm{~L}$ & 2.0 & 2.0 & 2.1 & $\mathrm{~L}$ & 2.0 & 3.0 & 2.3 & $\mathrm{~L}$ \\
\hline Acid casein & 1.0 & 2.0 & 1.5 & $\mathrm{~L}$ & 1.0 & 2.0 & 1.5 & $\mathrm{~L}$ & 1.0 & 2.0 & 1.4 & $\mathrm{P}$ & 1.0 & 2.0 & 1.5 & $\mathrm{~L}$ \\
\hline Sulfuric acid & 5.0 & 5.0 & 5 & E & 5.0 & 5.0 & 5 & E & 5.0 & 4.0 & 4.5 & $\mathrm{E}$ & 5.0 & 5.0 & 5.0 & E \\
\hline Nitric acid & 4.0 & 3.0 & 3.7 & $\mathrm{H}$ & 4.0 & 3.0 & 3.7 & $\mathrm{H}$ & 4.0 & 3.0 & 3.3 & $\mathrm{H}$ & 4.0 & 3.0 & 3.6 & $\mathrm{H}$ \\
\hline Chromic acid & 5.0 & 3.0 & 3.9 & $\mathrm{H}$ & 5.0 & 3.0 & 3.9 & $\mathrm{H}$ & 5.0 & 2.0 & 3.2 & M & 5.0 & 2.0 & 3.2 & M \\
\hline Acetic acid & 3.0 & 2.0 & 2.6 & M & 3.0 & 2.0 & 2.6 & M & 3.0 & 2.0 & 2.4 & $\mathrm{~L}$ & 3.0 & 2.0 & 2.6 & M \\
\hline Latex & 2.0 & 3.0 & 2.4 & $\mathrm{~L}$ & 2.0 & 3.0 & 2.4 & $\mathrm{~L}$ & 2.0 & 2.0 & 2.1 & $\mathrm{~L}$ & 2.0 & 3.0 & 2.3 & $\mathrm{~L}$ \\
\hline Zinc oxide & 2.0 & 2.0 & 2.2 & $\mathrm{~L}$ & 2.0 & 2.0 & 2.2 & $\mathrm{~L}$ & 2.0 & 2.0 & 1.9 & $\mathrm{~L}$ & 2.0 & 2.0 & 2.1 & $\mathrm{~L}$ \\
\hline 2-Benzothiazolethione & 1.0 & 2.0 & 1.5 & $\mathrm{~L}$ & 1.0 & 2.0 & 1.5 & $\mathrm{~L}$ & 1.0 & 2.0 & 1.4 & $\mathrm{P}$ & 1.0 & 2.0 & 1.5 & $\mathrm{~L}$ \\
\hline Diethylcarbamodithioato-S-S' & 2.0 & 2.0 & 2.2 & $\mathrm{~L}$ & 2.0 & 2.0 & 2.2 & $\mathrm{~L}$ & 2.0 & 2.0 & 1.9 & $\mathrm{~L}$ & 2.0 & 2.0 & 2.1 & $\mathrm{~L}$ \\
\hline Ammonia & 3.0 & 2.0 & 2.4 & $\mathrm{~L}$ & 3.0 & 2.0 & 2.4 & $\mathrm{~L}$ & 3.0 & 1.0 & 1.7 & $\mathrm{~L}$ & 3.0 & 2.0 & 2.4 & $\mathrm{~L}$ \\
\hline Titanium dioxide & 3.0 & 2.0 & 2.6 & M & 3.0 & 2.0 & 2.6 & M & 3.0 & 2.0 & 2.4 & $\mathrm{~L}$ & 3.0 & 2.0 & 2.6 & M \\
\hline Calcium carbonate & 2.0 & 3.0 & 2.3 & $\mathrm{~L}$ & 2.0 & 3.0 & 2.3 & $\mathrm{~L}$ & 2.0 & 2.0 & 2 & $\mathrm{~L}$ & 2.0 & 2.0 & 2.2 & $\mathrm{~L}$ \\
\hline Potassium hydroxide & 4.0 & 3.0 & 3.3 & $\mathrm{H}$ & 4.0 & 3.0 & 3.3 & $\mathrm{H}$ & 4.0 & 2.0 & 3 & M & 4.0 & 3.0 & 3.2 & M \\
\hline Paraffin & 1.0 & 2.0 & 1.5 & $\mathrm{~L}$ & 1.0 & 2.0 & 1.5 & $\mathrm{~L}$ & 1.0 & 2.0 & 1.4 & $\mathrm{P}$ & 1.0 & 2.0 & 1.5 & $\mathrm{~L}$ \\
\hline Sulfur & 4.0 & 2.0 & 3.1 & M & 4.0 & 2.0 & 3.1 & M & 4.0 & 2.0 & 2.7 & M & 4.0 & 2.0 & 3.0 & M \\
\hline kumanox & 1.0 & 3.0 & 1.8 & $\mathrm{~L}$ & 1.0 & 3.0 & 1.8 & $\mathrm{~L}$ & 1.0 & 2.0 & 1.6 & $\mathrm{~L}$ & 1.0 & 3.0 & 1.7 & $\mathrm{~L}$ \\
\hline
\end{tabular}

Table 7. Health Risk Assessment of Exposure to Chemical Contaminants Identified in Gloves Washing Unit

\begin{tabular}{|c|c|c|c|c|c|c|c|c|c|c|c|c|c|c|c|c|}
\hline \multirow[b]{3}{*}{ Material Name } & \multicolumn{16}{|c|}{ Unit } \\
\hline & \multicolumn{4}{|c|}{ Production operator } & \multicolumn{4}{|c|}{ Cart operator } & \multicolumn{4}{|c|}{ Maintenance } & \multicolumn{4}{|c|}{ Quality control } \\
\hline & 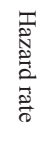 & 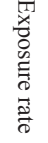 & 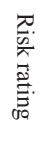 & $\begin{array}{l}\vec{D} \\
0 \\
o \\
\stackrel{0}{E} \\
\stackrel{0}{0}\end{array}$ & 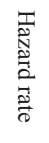 & 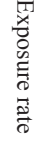 & 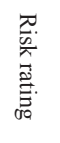 & $\begin{array}{l}\vec{D} \\
0 \\
0 \\
\stackrel{0}{\Xi} \\
\stackrel{0}{\Xi} \\
=\end{array}$ & 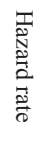 & 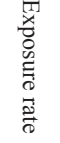 & 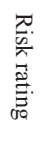 & $\begin{array}{l}\vec{D} \\
0 \\
0 \\
\stackrel{0}{E} \\
\stackrel{0}{0} \\
=\end{array}$ & 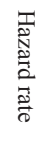 & 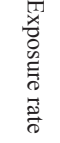 & 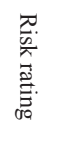 & $\begin{array}{l}\vec{D} \\
0 \\
0 \\
\stackrel{0}{E} \\
0 \\
巳\end{array}$ \\
\hline hydrochloric acid & 4.0 & 4.0 & 4.0 & $\mathrm{H}$ & 4.0 & 4.0 & 4.0 & $\mathrm{H}$ & 4.0 & 2.0 & 3.0 & $\mathrm{M}$ & 4.0 & 4.0 & 4.0 & $\mathrm{H}$ \\
\hline Chlorine & 3.0 & 4.0 & 3.6 & $\mathrm{H}$ & 3.0 & 4.0 & 3.5 & $\mathrm{H}$ & 3.0 & 3.0 & 2.9 & $\mathrm{M}$ & 3.0 & 4.0 & 3.5 & $\mathrm{H}$ \\
\hline Sodium hypochlorite & 3.0 & 3.0 & 3.0 & M & 3.0 & 3.0 & 3.0 & M & 3.0 & 2.0 & 2.4 & $\mathrm{~L}$ & 3.0 & 3.0 & 3.0 & $\mathrm{M}$ \\
\hline Ammonia & 3.0 & 2.0 & 2.4 & $\mathrm{~L}$ & 3.0 & 2.0 & 2.4 & $\mathrm{~L}$ & 3.0 & 1.0 & 1.7 & $\mathrm{~L}$ & 3.0 & 2.0 & 2.4 & $\mathrm{~L}$ \\
\hline
\end{tabular}

manufacturing industry based latex gloves because of carcinogens (IARC $=1$ Group) such as sulfuric acid and chromic acid, the acid with high PH Such as nitric acid, sulfuric acid, chromic acid, hydrochloric acid, etc., alkalis, with low $\mathrm{PH}$ such as potassium hydroxide and dangerous stimulants like ammonia level has high risk level because almost for each 7 known risk, one risk has high rank. In a study that Thyssen et al carried out in 2007 estimated that $15-20 \%$ of the general population in Western Europe and North America suffer from allergies caused by chemical substances (Thyssen, Linneberg et al. 2007). In a study that Jahangiri et al carried out in 2010 concluded that in chemical industry, risk exposure with sulfuric acid is in the middle range (Jahangiri and Parsarad 2010),

however, in the present study this dangerous acid were in the high $(\mathrm{H})$ and very high (E) range. In a study that Kocher et al carried out in 2002 noted that the health risk assessment is essential that all risk parameters were identified and assessed (Kocher and Greim, 2002). In the year 2012 Mckenzie et al noted in the application of risk assessment in determining the risks of chemical control strategies (McKenzie, Witter et al., 2012). In the present study, with an average of hazard rate due to the high level risks has been more effective, it is better that the inherent safety design strategy of latex gloves used in the industry was placed on the agenda because at this strategy with the removal and replacement of dangerous substances with a lower risk, risks are reduced. Inherent safety, which was introduced in 1970 by Kletz claims that in a process of identifying and eliminating the dangers of early, even before implementation are reduced risks program (Aven 2009, Hassim, Hurme et al., 2013), Kletz was one of the first people that summarized the activities inherent safety design production workshops in five popular term reduction, replacement, moderate-making, simplify and limit the effects (Kletz 2003). However, Cozzani states that the events of storage areas in the wake of a domino effect and may counteract these effects and must therefore inherent safety methods with methods of active and passive inherent safety design, these risks can 
be reduced (Cozzani, Tugnoli et al., 2007). Inherent safety design, the idea is to improve process safety performance through eliminating or reducing (internal strategy) rather than control or manage (external strategy) risks (Hassim, Hurme et al., 2013), on the other hand, because of the degree of exposure to the average of the high level of risk, was 3.5, control strategies can also be used for inherent safety complementary strategies, in this regard, Hong et al considers educational programs as one of the most effective methods used to reduce the health risks in the industry because it can have a positive effect on the motivation and belief of people in the implementation and deployment of control programs (Hong, Lin et al., 2004). In this study, the aim of the proposals based on the principles of inherent safety that the identity of the identified and available risks in industry were removed, thus, the researchers were suggested to do assessment and prioritize risks of industry to modify with inherent safety design approach, especially in the establishment step and more research done in this area.

\section{References}

Askham CA, Gade L, Hanssen OJ (2013). "Linking chemical risk information with life cycle assessment in product development. J Clean Prod, 51, 196-204.

Aven T (2009). Safety is the antonym of risk for some perspectives of risk. Safety Sci, 47, 925-30.

Callahan MA, Sexton M (2007). If cumulative risk assessment is the answer, what is the question?. Environ Health Perspect, 115,799-806

Cozzani V, Tugnoli A, Salzano E (2007). Prevention of domino effect: from active and passive strategies to inherently safer design. J Hazard Mater, 139, 209-19.

De Joode BVW, Vermeulen R, Van Hemmen J, Fransman W, Kromhout H (2005). Accuracy of a semiquantitative method for dermal exposure assessment (DREAM). J Occup Env Med, 62, 623-32.

Drexler H, Shukla, A (2014). Importance of exposure level for risk toxicological assessment. Regul Toxicol Pharmacol, 22, 569-75.

Egeghy PP, Vallero DA, Hubal EAC (2011). Exposure-based prioritization of chemicals for risk assessment. Environ Sci Policy, 14, 950-64.

Fromme H, Albrecht M, Angerer J (2007). Integrated exposure assessment survey (INES): exposure to persistent and bioaccumulative chemicals in Bavaria, Germany. Int J Hyg Environ Health, 210, 345-9.

Fryer M, Collins CD, Ferrier H, Colvile RN, Nieuwenhuijsen MJ (2006). Human exposure modelling for chemical risk assessment: a review of current approaches and research and policy implications. Environ Sci Policy, 9, 261-74.

Geraets L, Bessems JG, Zeilmaker MJ, Bos PM (2014). Human risk assessment of dermal and inhalation exposures to chemicals assessed by route-to-route extrapolation: The necessity of kinetic data. Regul Toxicol Pharmacol, 70, 54-64.

Hassim M, Edwards D (2006). Development of a methodology for assessing inherent occupational health hazards. Prosses Saf Environ J, 84, 378-90.

Hassim MH, Hurme M, Edwards DW, Aziz NN, Rahim FL (2013). Simple graphical method for inherent occupational health assessment. Prosses Saf Environ J, 91, 438-51.

Herber RFJ, Duffus H, Christensen JM, Olsen E, Park MV (2001). Risk assessment for occupational exposure to chemicals. A review of current methodology (IUPAC Technical Report). Pure Appl Chem, 73, 993-1031.

Hong YJ, Lin YH, Pai HH, Lai YC, Lee LN (2004). Developing a safety and health training model for petrochemical workers. Kaohsiung J Med Sci, 20, 56-61.

Jahangiri M, Parsarad M (2010). Health risk assessment of occupational exposure to harmful chemical agents. Int $J$ Occup Environ Med, 7, 18-24.

Kletz TA (2003). Inherently safer design its scope and future. Process Saf Environ Prot, 81, 401-5.

Kocher D, Greim H (2002). An approach to comparative assessments of potential health risks from exposure to radionuclides and hazardous chemicals. Environ Int, 27, 663-71.

Laforest L, Annino M, Alluard A (1999). Epidemiologic study of lead contamination of children of occupationally exposed parents. Rev Epidemiol Sante Publique, 47, 433-41.

Manpower MO (2002). Guidelines on risk assessment for occupational exposure to hurmful chemicals. Singapore, Occupational Health department.

Manpower MO (2005). A semi-quantitative method to assess occupational exposure to harmful chemicals. Singapore.

McKenzie LM, Witter RZ, Newman LS, Adgate JL (2012). Human health risk assessment of air emissions from development of unconventional natural gas resources. Sci Total Environ, 424, 79-87.

Mearns K, Yule S (2009). The role of national culture in determining safety performance: Challenges for the global oil and gas industry. Saf Sci , 47, 777-85.

Money C, Margary S (2002). Improved use of workplace exposure data in the regulatory risk assessment of chemicals within Europe. Ann Occup Hyg, 46, 279-85.

Normohammadi MH, Kakooei L, Omidi S, Yari S, Alimi R (2016). Risk assessment of exposure to silica dusts in building demolition sites Safety and Health at Work, (In Press).

Schenk L, Hansson SO, Rudén C, Gilek M (2008). Occupational exposure limits: A comparative study. Regul Toxicol Pharmacol, 50, 261-70.

Swaen G, Meijers J (1989). Risk assessment of leukaemia and occupational exposure to benzene. Br J Ind Med, 46, 826-30.

Thyssen JP, Linneberg A, Menné T, Johansen JD (2007). The epidemiology of contact allergy in the general population prevalence and main findings. Contact Derm, 57, 287-99.

Yari S (2015). Inherent safety design in compose of urban gas station. Safety Promot Inj Prev, 3, 135-140. 